\title{
Association of the TP53 codon 72 polymorphism and breast cancer risk: a meta-analysis
}

\author{
Meire Luzia Gonçalves' ${ }^{1}$ Sarah Moreira Borja', Jacqueline Andréia Bernardes Leão Cordeiro ${ }^{2}$, Vera Aparecida Saddi ${ }^{1,3,5}$, \\ Flávio Monteiro Ayres ${ }^{4}$, Cesar Augusto Sam Tiago Vilanova-Costa ${ }^{5}$ and Antonio Márcio Teodoro Cordeiro Silva $a^{1,5^{*}}$
}

\begin{abstract}
This study was conducted in order to investigate the implications of the R72P polymorphism in the TP53 gene in breast cancer risk. The enlightenment of this matter might provide a piece of information about the potential implications of this polymorphism in patient risk. A meta-analysis was conducted considering a large sample size from studies with conflicting results on the R72P polymorphism in breast cancer patients. Relevant studies were selected from PubMed and SciELO databases for data extraction and statistical analysis. Database was built according to the continent and considering the genotype frequencies, sample size and genotyping methodology. The dominant models (RR vs RP + PP and RR + RP vs. PP), homozygous (RR vs. PP), heterozygous (RR vs. RP and RP vs. PP) and the allele (R vs. P) were used. Genotype frequencies were summarized and evaluated by $x^{2}$ test of heterogeneity in $2 \times 2$ contingency tables with $95 \%$ Cls. Odds Ratios (OR) were calculated with a fixed-effect model (Mantel-Haenszel) or a random-effect model (DerSimonian-Laird) if the studies were considered homogeneous $(P>0.05)$ or heterogeneous $(P<0.05)$, respectively, using BioEstat ${ }^{\circledR} 5.0$ software. Supported by a large sample size composed by 25,629 cases and 26,633 controls from 41 studies, we found significant association between the R72P polymorphism in the TP53 gene and the breast cancer risk. The overall data shows an increased risk due to the P allele dominant model, but not in Asia where the risk was associated with the $\mathrm{R}$ allele and $\mathrm{R}$ dominant model.
\end{abstract}

Keywords: Arg72Pro; Genetic susceptibility; p53; R72P; Single nucleotide polymorphism; Breast cancer

\section{Introduction}

The R72P polymorphism in the TP53 gene results of the transversion $\mathrm{G} \rightarrow \mathrm{C}$ in the second position of the codon 72 at exon 4 . Both the polymorphic alleles vary among ethnic groups (Dokianakis et al. 2000) and geographic location, where the $\mathrm{P}$ allele is more frequent toward the equador line purportedly as a protective factor against UV rays (Damin et al. 2006; Olivier et al. 2002). P53 variant proteins have an arginine $(\mathrm{R})$ or a proline $(\mathrm{P})$ encoded by codon 72 , which differ in structure and function, specially concerning cell cycle progress (ChangClaude et al. 2009; Schmidt et al. 2009; Thomas et al. 1999; Petitjean et al. 2007; Dumont et al. 2003).

\footnotetext{
* Correspondence: marciocmed@gmail.com

${ }^{1}$ Departamento de Medicina, Pontifícia Universidade Católica de Goiás, Av. Universitária 1.069, Setor Universitário, Goiânia, Goiás CEP 74.605-010, Brazil ${ }^{5}$ Programa de Pós-Graduação Stricto Sensu em Ciências Ambientais e Saúde, Pontifícia Universidade Católica de Goiás, Goiânia, Goiás CEP 74065-140, Brazil

Full list of author information is available at the end of the article
}

Breast cancer is an heterogeneous sporadic or hereditary disease (Lima et al. 2006). The hereditary syndrome affects $10 \%$ of patients, of which $5 \%$ has high penetrance mutations in genes like BRAC1 and BRCA2 (BRCA1/2) (Pinto et al. 2007). BRCA1/2 and TP53 are susceptibility genes that confer high-risk of breast cancer (Oluwagbemiga et al. 2012). Evidences that the R72P polymorphisms in the TP53 gene can differently promote the transcription of $B R A C 1 / 2$ have widely supported studies on R72P role in breast tumorigenesis (Sinilnikova et al. 2009; Lum et al. 2008; Osorio et al. 2008; Gochhait et al. 2007; Cavallone et al. 2008; Baynes et al. 2007; Tommiska et al. 2005; Martin et al. 2003; Huang et al. 2003), e.g., (1) the P variant binds greater to transcriptional machinery (Thomas et al. 1999) and thus shows higher rates of G1 arrest than the $R$ variant protein (Petitjean et al. 2007; Gochhait et al. 2007); (2) the decreased efficiency of the $\mathrm{P}$ variant at triggering apoptosis (ChangClaude et al. 2009; Dumont et al. 2003), mainly due to its decreased ubiquination by MDM2 (Sinilnikova et al.

\section{Springer}


2009; Lum et al. 2008; Gochhait et al. 2007; Francisco et al. 2010) and to its increased efficiency to bind the inhibitor of apoptosis-stimulating protein of p53 (iASPP) (Schmidt et al. 2009; Bergamaschi et al. 2006).

In the present study, a meta-analysis was conducted considering a large sample size from studies with conflicting results on the R72P polymorphism in breast cancer patients. The enlightenment of this matter might provide a piece of information about the potential implications of this polymorphism in patient's risk.

\section{Material and methods}

\section{Identification and eligibility of relevant studies}

A literature search was conducted in SciELO (Scientific Eletronic Library Online) and PubMed databases by using the keywords: p53, polymorphism, breast cancer. Additional studies were searched among the references surveyed in the databases. Eligible studies were selected regardless of sample size, but had to meet the following criteria of inclusion: (a) the studies were published from 2002 to 2012; (b) the association between the R72P polymorphism and breast cancer were investigated; (c) the studies were case-control design; (d) genotyping was carried out by molecular biology methods, such as PCR, RFLP-PCR and DNA sequencing; (e) the reference was published in English; (f) histological confirmation of breast cancer diagnosis was performed; and $(\mathrm{g})$ the genotype distributions were available for estimating odds ratios (OR) and 95\% confidence intervals $(\mathrm{CI})$.

\section{Data extraction}

Two investigators independently extracted data and reached a consensus on all of the items. A third investigator took part of data extraction in case of disagreement in any of the items. The data extracted regarded country of origin, first author, and year of publication, number of cases and controls, and genotype frequencies.

\section{Statistical analysis}

In the current meta-analysis, the dominant models (RR vs $\mathrm{RP}+\mathrm{PP}$ and $\mathrm{RR}+\mathrm{RP}$ vs. $\mathrm{PP})$, homozygous (RR vs. $\mathrm{PP}$ ), heterozygous (RR vs. RP and RP vs. PP) and the allele ( $\mathrm{R}$ vs. $\mathrm{P}$ ) were used. Genotype frequencies were summarized and evaluated by $x^{2}$ test of heterogeneity in $2 \times 2$ contingency tables with 95\% CIs (Böhning et al. 2002). Odds Ratios (OR) were calculated with a fixed-effect model (Mantel-Haenszel) or a random-effect model (DerSimonian-Laird) if the studies were considered homogeneous $(P>0.05)$ or heterogeneous $(P<0.05)$, respectively. The OR and their corresponding 95\% CI were used to test the association between the 72 codon polymorphism and breast cancer. All analyses were performed with BioEstat ${ }^{\circ} 5.0$ software. To estimate a combined effect, OR were calculated for both fixed and random effect

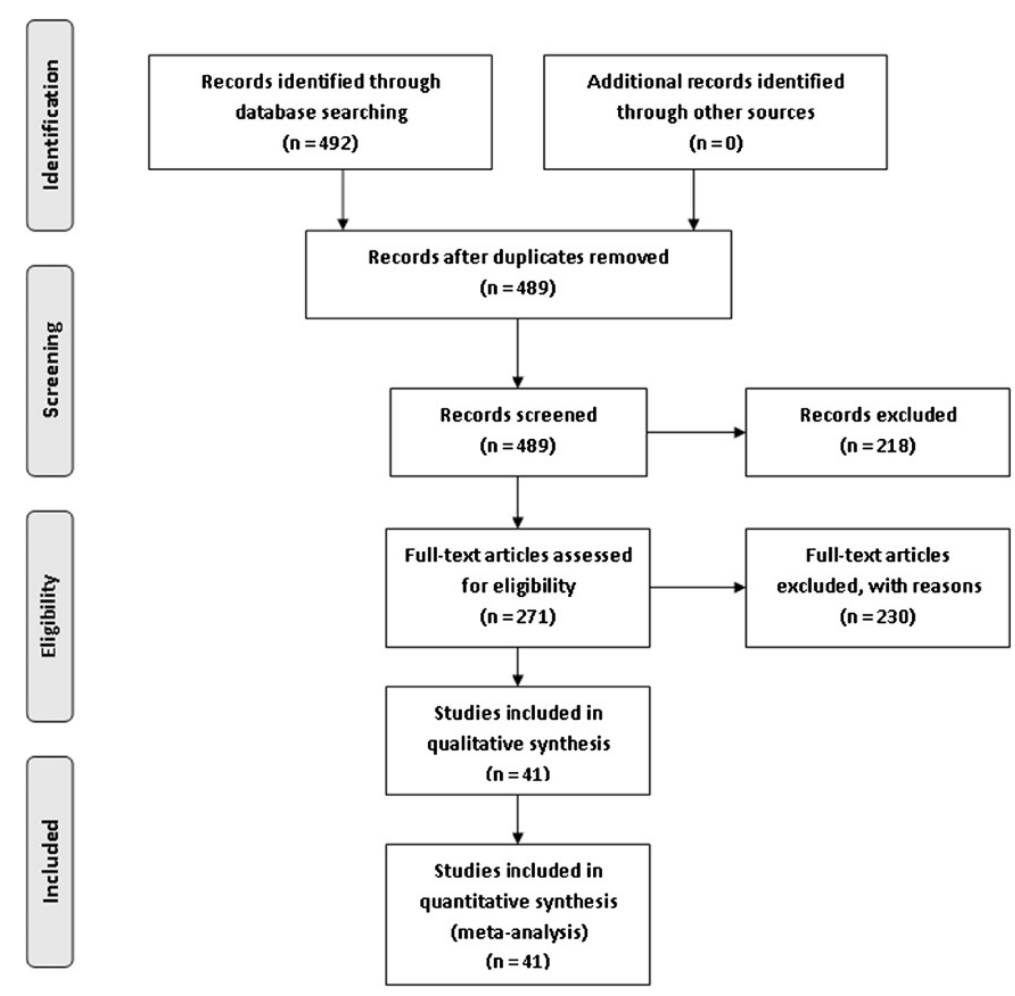

Figure 1 Flow diagram of the studies evaluated for meta-analysis. 
analyses, by applying 95\% CIs and individual or combined weights for the studies ( $\mathrm{Li}$ et al. 2012; Conn et al. 2012; Manning et al. 2011; Higgins et al. 2008).

\section{Results and discussion}

\section{Study inclusion and characteristics}

A total of 492 studies were screened, of which three were found in both PubMed and SciELO. From the 489 studies screened, 218 were published before 2002 and 20 were reviews or published in another language than English, or both. The remaining 271 records were assessed for eligibility and 41 fulfilled the criteria of inclusion (Figure 1). From the selected studies, a database was built considering the continent, genotype frequencies, sample size and genotype methodology. All together, the 41 studies that met the inclusion criteria and were identified as eligible article, yielding 25,629 cases and 26,633 controls.

In the last 10 years, eligible studies on R72P polymorphism in the TP53 gene in breast cancer were mostly from Europe with 19 articles, followed by Asia, America and Africa with 14, 6 and 2, respectively. Subject's age was collected, when available, showing that mean age of patients was 51.9 y.o. and of control subjects 48.1 y.o. The genotyping for p53 codon 72 polymorphism was performed using Polymerase Chain Reaction (PCR), AlleleSpecific PCR (AS-PCR), Amplifluor ${ }^{\circ}$ GoldenGate Genotyping Assay (GGA), PCR-Denaturing Gradient Gel Electrophoresis (PCR-DGGE), PCR-Restriction Fragment Length Polymorphism (PCR-RFLP), sequencing and Taqman PCR. Breast cancer patients and controls subjects were mainly heterozygous in Asia (50.1\%; 48.0\%) and Africa (43.9\%; 49.7\%), while the RR homozygous was predominant in America (53.6\%; 54.5\%) and Europe (54.1\%; 53.4\%). The $\mathrm{R}$ allele was predominant in breast cancer patients from America and Europe (73.3\%, each), Africa (63.2\%) and Asia (58.3\%).

\section{Quantitative synthesis}

The dominant models $\mathrm{RR}+\mathrm{RP}$ vs. $\mathrm{PP}$ and $\mathrm{RR} v s . \mathrm{RP}+$ PP had OR calculated using a random-effect model. No association between breast cancer risk and the dominant model RR + RP vs. PP (OR = 1.09; 95\% CI 0.98-1.22) was found (Figure 2 and Table 1). By the other hand, our findings for $\mathrm{RR} v s . \mathrm{RP}+\mathrm{PP}(\mathrm{OR}=1.11 ; 95 \% \mathrm{CI} 1.02-1.21)$ showed a markedly increased risk of breast cancer associated with the RP and PP genotypes, considering the $\mathrm{P}$

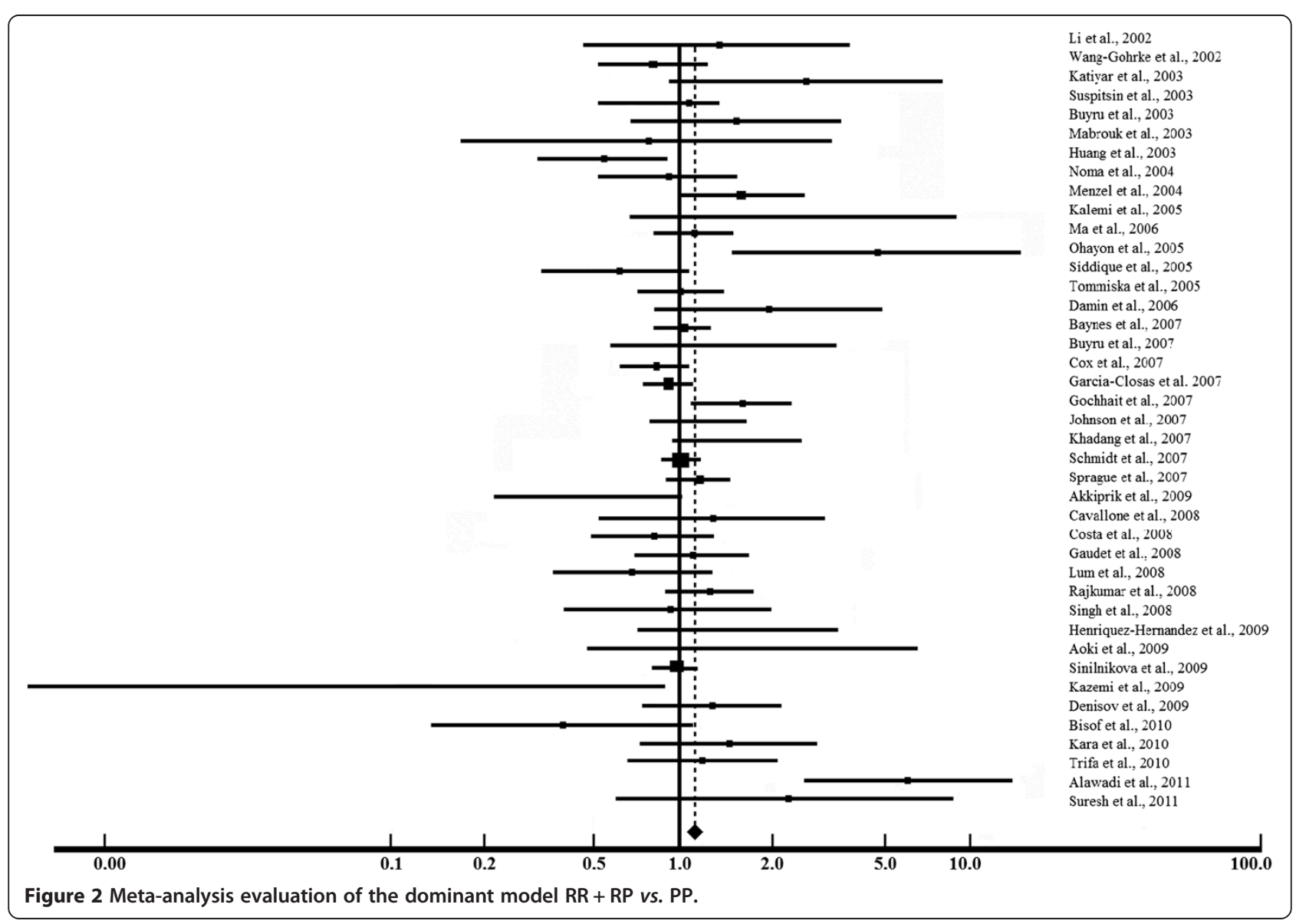


Table 1 Meta-analysis of the R72P polymorphism of the gene TP53 on breast cancer

\begin{tabular}{|c|c|c|c|c|}
\hline Studies/continent & $\begin{array}{l}\text { No. of case/ } \\
\text { control }\end{array}$ & $\begin{array}{c}\text { RR + RP vs. PP } \\
\text { OR }(95 \% \mathrm{Cl})\end{array}$ & $\begin{array}{c}\text { RR vs. RP + PP } \\
\text { OR }(95 \% \mathrm{Cl})\end{array}$ & $\begin{array}{c}\text { R vs. P } \\
\text { OR }(95 \% \mathrm{Cl})\end{array}$ \\
\hline Africa & $\Sigma=189 / 181$ & $1.13(0.64-2.01)$ & $1.40(0.91-2.15)$ & $1.16(0.86-1.56)$ \\
\hline Trifa et al., 2010 & 159/132 & $1.19(0.65-2.19)$ & $1.21(0.75-1.96)$ & $1.15(0.83-1.61)$ \\
\hline Mabrouk et al., 2003 & $30 / 49$ & $0.78(0.18-3.40)$ & $2.32(0.93-5.78)$ & $1.59(0.78-3.27)$ \\
\hline America & $\Sigma=6,483 / 8,011$ & $0.99(0.87-1.12)$ & $1.05(0.88-1.26)$ & $0.98(0.92-1.02)$ \\
\hline Damin et al., 2006 & $118 / 202$ & $2.05(0.83-5.09)$ & $2.22(1.40-3.53)$ & $1.79(1.25-2.55)$ \\
\hline Aoki et al., 2009 & $72 / 90$ & $1.78(0.48-6.60)$ & $2.47(1.31-4.66)$ & $1.85(1.14-3.00)$ \\
\hline Gaudet et al., 2008 & $578 / 390$ & $1.11(0.70-1.76)$ & $0.78(0.61-1.01)$ & $0.88(0.71-1.08)$ \\
\hline Cox et al., 2007 & $1,477 / 2,224$ & $0.83(0.63-1.08)$ & $0.92(0.81-1.05)$ & $0.92(0.83-1.02)$ \\
\hline Garcia-Closas et al. 2007 & $2,585 / 3,251$ & $0.92(0.75-1.12)$ & $0.94(0.84-1.04)$ & $0.95(0.87-1.03)$ \\
\hline Sprague et al., 2007 & $1,653 / 1,854$ & $1.16(0.89-1.52)$ & $1.00(0.87-1.14)$ & $1.02(0.92-1.14)$ \\
\hline Asia & $\Sigma=2,570 / 2,833$ & $1.21(0.89-1.64)$ & $1.08(0.89-1.32)$ & *1.09 (1.01-1.17) \\
\hline Lum et al., 2008 & $393 / 80$ & $0.69(0.37-1.30)$ & $0.64(0.39-1.06)$ & $0.73(0.51-1.03)$ \\
\hline Gochhait et al., 2007 & $243 / 333$ & $1.66(1.12-2.46)$ & $1.85(1.28-2.67)$ & $1.56(1.23-1.92)$ \\
\hline Huang et al., 2003 & $200 / 282$ & $0.54(0.32-0.92)$ & $0.70(0.48-1.02)$ & $0.72(0.55-0.93)$ \\
\hline Ma et al. 2006 & $404 / 472$ & $1.14(0.82-1.59)$ & $1.25(0.95-1.66)$ & $1.16(0.96-1.40)$ \\
\hline Rajkumar et al., 2008 & $250 / 500$ & $1.27(0.89-1.80)$ & $0.97(0.69-1.37)$ & $1.08(0.87-1.34)$ \\
\hline Li et al., 2002 & $28 / 50$ & $1.38(0.48-3.99)$ & $2.54(0.93-6.94)$ & $1.68(0.87-3.27)$ \\
\hline Alawadi et al., 2011 & 288/188 & $6.12(2.66-14.08)$ & $1.08(0.71-1.63)$ & $1.31(1.00-1.71)$ \\
\hline Suresh et al., 2011 & $35 / 37$ & $2.28(0.59-8.91)$ & $0.95(0.35-2.57)$ & $1.21(0.62-2.34)$ \\
\hline Kazemi et al., 2009 & $42 / 57$ & $0.05(0.003-0.89)$ & $0.65(0.23-1.84)$ & $0.65(0.37-1.15)$ \\
\hline Singh et al., 2008 & $104 / 105$ & $0.91(0.40-2.06)$ & $2.26(1.21-3.85)$ & $1.42(0.96-2.11)$ \\
\hline Khadang et al., 2007 & $221 / 205$ & $1.60(0.95-2.68)$ & $1.04(0.70-1.54)$ & $1.17(0.89-1.54)$ \\
\hline Siddique et al., 2005 & $94 / 265$ & $0.62(0.34-1.12)$ & $0.92(0.57-1.49)$ & $0.83(0.59-1.16)$ \\
\hline Noma et al., 2004 & $191 / 218$ & $0.93(0.54-1.60)$ & $0.92(0.62-1.35)$ & $0.82(0.61-1.10)$ \\
\hline Katiyar et al., 2003 & $77 / 41$ & $2.79(0.93-8.39)$ & $1.22(0.51-2.95)$ & $1.38(0.80-2.36)$ \\
\hline Europe & $\Sigma=16,387 / 15,608$ & $1.03(0.95-11.25)$ & $1.13(1.00-1.27)$ & $1.02(0.99-1.06)$ \\
\hline Sinilnikova et al., 2009 & $3,959 / 3,052$ & $0.97(0.80-1.16)$ & $1.01(0.92-1.11)$ & $1.00(0.93-1.08)$ \\
\hline Cavallone et al., 2008 & 157/112 & $1.29(0.52-3.21)$ & $1.00(0.62-1.63)$ & $1.04(0.71-1.53)$ \\
\hline Baynes et al., 2007 & $2,023 / 2,197$ & $1.04(0.82-1.30)$ & $1.05(0.93-1.18)$ & $1.04(0.95-1.14)$ \\
\hline Tommiska et al., 2005 & $1,551 / 733$ & $1.02(0.72-1.43)$ & $0.93(0.78-1.11)$ & $0.96(0.83-1.10)$ \\
\hline Akkiprik et al. 2009 & $95 / 108$ & $0.39(0.14-1.12)$ & $1.38(0.78-2.42)$ & $1.02(0.65-1.91)$ \\
\hline Kara et al., 2010 & 204/192 & $1.48(0.73-3.00)$ & $1.45(0.98-2.15)$ & $1.34(0.99-1.81)$ \\
\hline Bisof et al., 2010 & $95 / 107$ & $0.48(0.22-1.04)$ & $0.48(0.27-0.87)$ & $0.58(0.39-0.86)$ \\
\hline Denisov et al., 2009 & $297 / 275$ & $1.28(0.73-2.23)$ & $0.87(0.62-1.20)$ & $0.96(0.75-1.25)$ \\
\hline Henrıquez-Hernandez et al. 2009 & $135 / 295$ & $1.60(0.72-3.54)$ & $0.90(0.60-1.36)$ & $1.03(0.74-1.43)$ \\
\hline Costa et al., 2008 & $248 / 646$ & $0.81(0.49-1.32)$ & $0.86(0.64-1.16)$ & $0.87(0.69-1.10)$ \\
\hline Buyru et al., 2007 & $115 / 63$ & $1.44(0.58-3.57)$ & $1.77(0.96-3.29)$ & $1.52(0.96-2.43)$ \\
\hline Johnson et al., 2007 & $472 / 2,462$ & $1.17(0.79-1.74)$ & $0.98(0.80-1.19)$ & $1.01(0.87-1.19)$ \\
\hline Schmidt et al. 2007 & $5,191 / 3,834$ & $1.01(0.86-1.18)$ & $1.05(0.96-1.14)$ & $1.03(0.96-1.10)$ \\
\hline Kalemi et al., 2005 & $42 / 51$ & $2.52(0.69-9.26)$ & $6.35(2.54-15.84)$ & $3.29(1.73-6.25)$ \\
\hline Ohayon et al., 2005 & 132/167 & $4.86(1.52-15.53)$ & $4.29(4.68-6.96)$ & $3.10(2.10-4.56)$ \\
\hline Menzel et al., 2004 & $475 / 302$ & $1.64(0.97-2.76)$ & $1.25(0.94-1.67)$ & $1.27(1.01-1.60)$ \\
\hline Buyru et al., 2003 & $115 / 76$ & $1.61(0.69-3.73)$ & $3.23(1.7-6.00)$ & $2.09(1.36-3.22)$ \\
\hline
\end{tabular}


Table 1 Meta-analysis of the R72P polymorphism of the gene TP53 on breast cancer (Continued)

\begin{tabular}{lcccc}
\hline Suspitsin et al., 2003 & $529 / 393$ & $0.86(0.52-1.41)$ & $1.04(0.80-1.35)$ & $1.00(0.81-1.23)$ \\
Wang-Gohrke et al., 2002 & $552 / 543$ & $0.82(0.53-1.26)$ & $0.85(0.67-1.07)$ & $0.87(0.72-1.05)$ \\
Overall & $25,629 / 26,633$ & $1.09(0.98-1.22)$ & $* 1.11(1.02-1.21)$ & $1.02(1.00-1.05)$ \\
Heterogeneity & & $X^{2}=80.19$ & $X^{2}=146.02$ & $X^{2}=6.54$ \\
& & $P=0.0002$ & $P<0.0001$ & $P=0.088$ \\
\hline
\end{tabular}

allele as dominant (Figure 3 and Table 1). In agreement with our results, the PP genotype was previously associated with higher risk for breast cancer (Huang et al. 2003; Rajkumar et al. 2008). Among unselected breast cancer patients, the PP genotype also predicted poor survival and a 2-fold increased risk of death (Tommiska et al. 2005).

The $\mathrm{P}$ allele has been associated with earlier breast cancer onset in BRCA1/2 mutation carriers (Tommiska et al. 2005; Martin et al. 2003), probably due to penetrance modification in BRCA1 (Martin et al. 2003) and to the lower ability of the $\mathrm{P}$ variant to induce apoptosis in genotoxic stress (Chang-Claude et al. 2009; Dumont et al. 2003). However, most of the studies selected for this meta-analysis have failed to detect any implication of R72P to breast cancer risk. Among most of the selected references, no risk modification by R72P was found in wild type BRCA1/2 and mutation carriers, even if the age of diagnosis or tumor stage were regarded (Sinilnikova et al. 2009; Lum et al. 2008; Cavallone et al. 2008; Baynes et al. 2007; Tommiska et al. 2005). Our overall data showed an association of risk increase with PP genotype, but not with the alleles alone ( $\mathrm{R} v s$. P; OR = 1.02; 95\% CI 1.00-1.05), as described in Table 1. The lack of implication concerning $\mathrm{P}$ allele alone might be explained by the $\mathrm{R}$ allele in the heterozygous, because the $R$ variant may act in a codominant mode to decrease breast cancer risk and to detain the onset in sporadic cases (Lum et al. 2008). Although our overall data show no association with the alleles alone, the analysis of 2,570 cases and 2,833 controls from Asia demonstrated a markedly increase of the $\mathrm{R}$ allele frequency in breast cancer

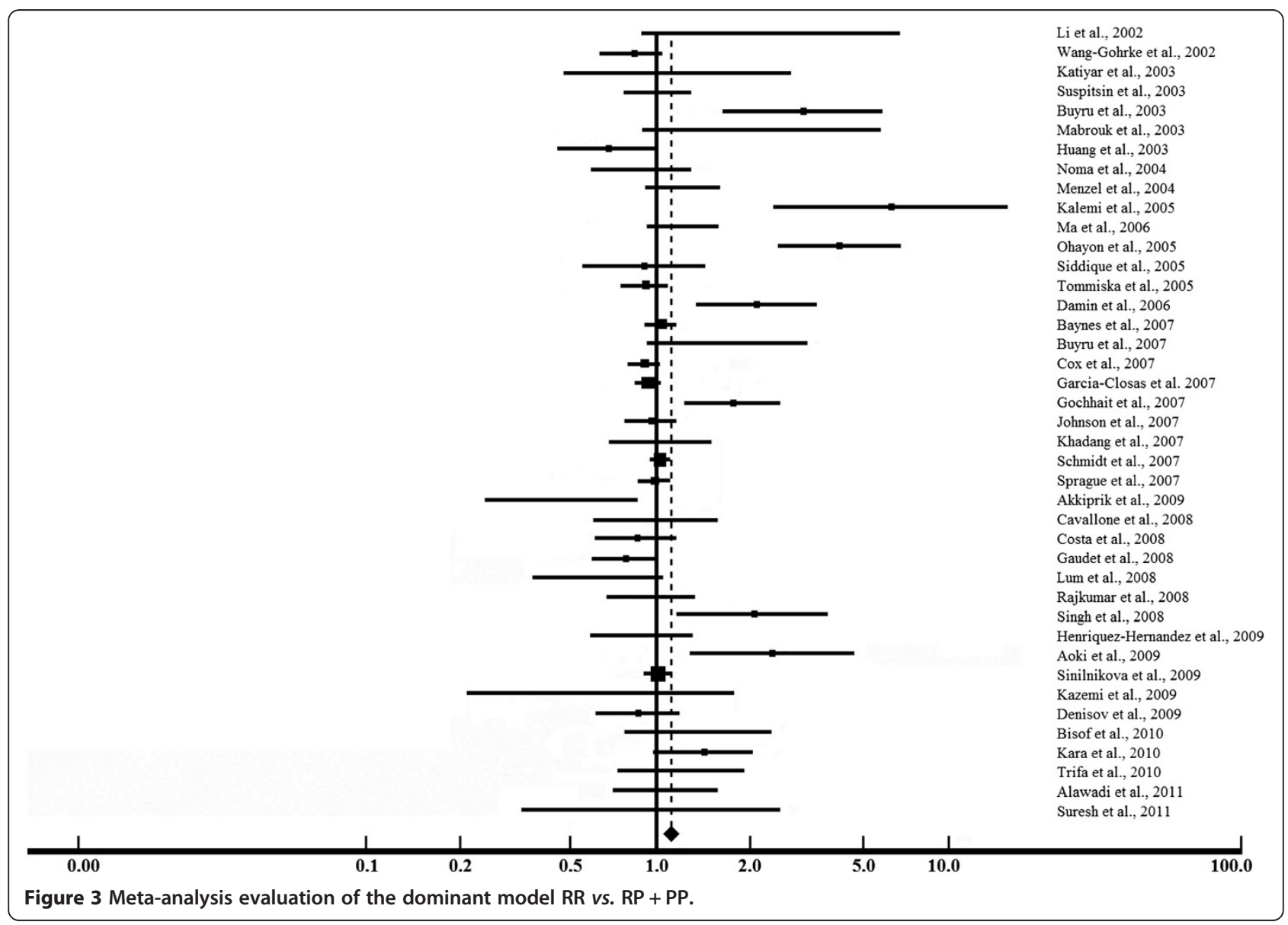


Table 2 Meta-analysis of the R72P polymorphism of the gene TP53 on breast cancer, by pooling data per continent

\begin{tabular}{|c|c|c|c|c|c|}
\hline & $\begin{array}{c}\text { RR vs. RP } \\
\text { OR (95\% CI) }\end{array}$ & $\begin{array}{c}\text { RR vs. PP } \\
\text { OR }(95 \% \mathrm{Cl})\end{array}$ & $\begin{array}{c}\text { RP vs. PP } \\
\text { OR }(95 \% \mathrm{Cl})\end{array}$ & $\begin{array}{l}\text { RR+RP vs. PP } \\
\text { OR }(95 \% \mathrm{Cl})\end{array}$ & $\begin{array}{l}\text { RR vs. RP+PP } \\
\text { OR }(95 \% \mathrm{Cl})\end{array}$ \\
\hline Africa & $1.41(0.90-2.22)$ & $1.30(0.69-2.44)$ & $0.99(0.54-1.83)$ & $1.05(0.6-1.86)$ & $1.32(0.86-2.01)$ \\
\hline America & $1.04(0.87-1.23)$ & $1.04(0.82-1.33)$ & $1.01(0.88-1.16)$ & $0.98(0.86-1.11)$ & $0.96(0.90-1.03)$ \\
\hline Asia & $1.05(0.88-1.26)$ & $1.24(0.87-1.78)$ & $1.15(0.85-1.57)$ & ${ }^{*} 1.23(1.07-1.41)$ & $1.04(0.93-1.17)$ \\
\hline Europe & $1.09(0.97-1.22)$ & $1.10(0.93-1.31)$ & $1.01(0.92-1.11)$ & $1.04(0.95-1.13)$ & $1.03(0.98-1.08)$ \\
\hline Overall & $1.01(0.97-1.04)$ & $1.05(0.99-1.12)$ & $1.05(0.99-1.12)$ & $1.06(0.99-1.12)$ & $1.05(0.98-1.05)$ \\
\hline \multirow[t]{2}{*}{ Heterogeneity } & $x^{2}=3.91$ & $x^{2}=5.42$ & $x^{2}=5.78$ & $x^{2}=6.15$ & $x^{2}=4.53$ \\
\hline & $P=0.27$ & $P=0.14$ & $P=0.12$ & $P=0.10$ & $P=0.21$ \\
\hline
\end{tabular}

patients ( $\mathrm{R}$ vs. $\mathrm{P} ; \mathrm{OR}=1.09 ; 95 \%$ CI 1.01-1.17), as detailed in Table 1.

Ethnic and geographical nonspecific factors, further to allele frequencies variations in different health populations, have been argued as the reason to the controversial data on R72P role in breast cancer (Dokianakis et al. 2000; Lum et al. 2008; Huang et al. 2003). Worth of note in this regard is that, in our meta-analysis, $\mathrm{R}$ allele was the most frequent in patients and control subjects, featuring the allele frequencies as a potential ethnic or geographical risk factor. By pooling all studies per continent, we performed the analyses of the dominant models and the genotypes using the fixed-effect model. Our overall results showed no association of the R72P polymorphism with breast cancer, but Asian patients had an increased risk associated with the dominant model $\mathrm{RR}+\mathrm{RP}$ vs. PP $(\mathrm{OR}=1.23$; 95\% CI 1.07-1.41), as described in Table 2 . These remarkable data concerning $\mathrm{RR}+\mathrm{RP}$ genotypes and $\mathrm{R}$ allele in Asia are in agreement with the reports that $\mathrm{R}$ variant increased breast risk in patients from China (Weston \& Godbold 1997; Li et al. 2002) and India (Gochhait et al. 2007). In contrast, previous meta-analysis designed studies failed to correlate the R72P polymorphism with breast cancer (Ma et al. 2006; Zhuo et al. 2009), even when subjects were stratified by ethnicity or source of controls (Ma et al. 2011).

In conclusion, we found significant association between the R72P polymorphism in the TP53 gene and the breast cancer risk. The overall data showed an increased risk due to the P allele dominant model, but not in Asia where the risk was associated with the $\mathrm{R}$ allele and $\mathrm{R}$ dominant model. The present meta-analysis is supported by a large sample size composed by 25,629 cases and 26,633 controls from 41 studies.

\section{Competing interests}

The authors declare that they have no competing interests. There are no financial or personal interests that might be viewed as inappropriate influences on the work presented herein. This manuscript was completely financed by governmental and nonprofit institutions, Foundation for the Support of Research in the State of Goiás (FAPEG), Coordination for the Advancement of Higher Education Staff (CAPES) and Brazilian Ministry of Education (MEC).

\section{Authors' contributions}

The work presented here was carried out in collaboration between all authors. AMTCS, MLG and SMB conceived and designed the study. MLG, $S M B$ and AMTCS reviewed the papers for inclusion in the meta-analysis. $M L G, S M B, J A B L C$ and AMTCS coded the studies for the moderation tests. AMTCS performed the effect size calculations and moderation tests. AMTCS analyzed the data. MLG, SMB, AMTCS and VAS wrote the paper. FMA and CASTVC reviewed the manuscript. All authors have contributed to, seen and approved the manuscript.

\section{Acknowledgements}

The authors gratefully acknowledge the financial support of Brazilian Ministry of Education (MEC) through University for Everyone Program (PROUNI) fellowship to Meire Luzia Gonçalves and Foundation for the Support of Research in the State of Goiás (FAPEG) and Coordination for the Advancement of Higher Education Staff (CAPES) through fellowship to Jacqueline Andréia Bernardes Leão Cordeiro and Cesar Augusto Sam Tiago Vilanova-Costa.

\section{Author details}

'Departamento de Medicina, Pontifícia Universidade Católica de Goiás, Av. Universitária 1.069, Setor Universitário, Goiânia, Goiás CEP 74.605-010, Brazil. ${ }^{2}$ Faculdade de Enfermagem, Universidade Federal de Goiás, Goiânia, Goiás CEP 74605-080, Brazil. 'ªboratório de Oncogenética e Radiobiologia, Hospital Araújo Jorge, Associação de Combate ao Câncer em Goiás, Goiânia, Goiás CEP 74605-070, Brazil. “ Unidade Universitária de Ciências Exatas e Tecnológicas, Universidade Estadual de Goiás, Anápolis, Goiás CEP 75132-400, Brazil. ${ }^{5}$ Programa de Pós-Graduação Stricto Sensu em Ciências Ambientais e Saúde, Pontifícia Universidade Católica de Goiás, Goiânia, Goiás CEP 74065-140, Brazil.

Received: 10 November 2014 Accepted: 11 November 2014 Published: 17 December 2014

\section{References}

Akkiprik M, Sonmez O, Gulluoglu BM, Caglar HB, Kaya H, Demirkalem P, Abacioglu U, Sengoz M, Sav A, Ozer A (2009) Analysis of p53 gene polymorphisms and protein over-expression in patients with breast cancer. Pathol Oncol Res 15:359-368

Alawadi S, Ghabreau L, Alsaleh M, Abdulaziz Z, Rafeek M, Alkhalaf M (2011) P53 gene polymorphisms and breast cancer risk in Arab women. Med Oncol 3:709-715

Aoki MN, da Silva AHAC, Amarante MK, Do Val Carneiro JL, Fungaro MH, Watanabe MA (2009) CCR5 and p53 codon 72 gene polymorphisms: implications in breast cancer development. Int J Mol Med 23:429-435

Baynes C, Healey CS, Pooley KA, Scollen S, Luben RN, Thompson DJ, Pharoah PD, Easton DF, Ponder BA, Dunning AM (2007) SEARCH breast cancer study: common variants in the ATM, BRCA1, BRCA2, CHEK2 and TP53 cancer susceptibility genes are unlikely to increase breast cancer risk. Breast Cancer Res 9(2):R27

Bergamaschi D, Samuels Y, Sullivan A, Zvelebil M, Breyssens H, Bisso A, Del Sal G, Syed N, Smith P, Gasco M, Crook T, Lu X (2006) iASPP preferentially binds p53 proline-rich region and modulates apoptotic function of codon 72-polymorphic p53. Nat Genet 38(10):1133-1141 
Bisof V, Salihović MP, Narancić NS, Skarić-Jurić T, Jakić-Razumović J, Janićijević B, Turek S, Rudan P (2010) TP53 gene polymorphisms and breast cancer in Croatian women: a pilot study. Eur J Gynaecol Oncol 31(5):539-544

Böhning D, Malzahn U, Dietz E, Schlattmann P, Viwatwongkasem C, Biggeri A (2002) Some general points in estimating heterogeneity variance with the DerSimonian-Laird estimator. Biostatistics 3(4):445-457

Buyru N, Tigli H, Dalay N (2003) P53 codon 72 polymorphism in breast cancer. Oncol Rep 10:711-714

Buyru N, Altinisik J, Demokan S, Dalay N (2007) p53 genotypes and haplotypes associated with risk of breast cancer. Cancer Detect Prev 31:207-213

Cavallone L, Arcand SL, Maugard C, Ghadirian P, Mes-Masson AM, Provencher D, Tonin PN (2008) Haplotype analysis of TP53 polymorphisms, Arg72Pro and Ins16, in BRCA1 and BRCA2 mutation carriers of French Canadian descent. BMC Cancer 8:96

Chang-Claude J, Ambrosone CB, Lilla C, Kropp S, Helmbold I, von Fournier D, Haase W, Sautter-Bihl ML, Wenz F, Schmezer P, Popanda O (2009) Genetic polymorphisms in DNA repair and damage response genes and late normal tissue complications of radiotherapy for breast cancer. Br J Cancer 100(10):1680-1686

Conn VS, Ruppar TM, Phillips LJ, Chase J-AD (2012) Using meta-analyses for comparative effectiveness research. Nurs Outlook 60:182-190

Costa S, Pinto D, Pereira D, Rodrigues H, Cameselle-Teijeiro J, Medeiros R, Schmitt F (2008) Importance of TP53 codon 72 and intron 3 duplication 16 bp polymorphisms in prediction of susceptibility on breast cancer. BMC Cancer 8:32

Cox DG, Deer D, Guo Q, Tworoger SS, Hankinson SE, Hunter DJ, De Vivo I (2007) The p53 Arg72Pro and MDM2-309 polymorphisms and risk of breast cancer in the nurses' health studies. Cancer Causes Control 18:621-625

Damin AP, Frazzon AP, Damin DC, Roehe A, Hermes V, Zettler C, Alexandre CO (2006) Evidence for an association of TP53 codon 72 polymorphism with breast cancer risk. Cancer Detect Prev 30:523-529

Denisov EV, Cherdyntseva NV, Litvyakov NV, Slonimskaya EM, Malinovskaya EA, Voevoda MI, Belyavskaya VA, Stegniy VN (2009) TP53 mutations and Arg72Pro polymorphism in breast cancers. Cancer Genet Cytogenet 192(2):93-95

Dokianakis DN, Koumantaki E, Billiri K, Spandidos DA (2000) P53 codon 72 polymorphism as a risk factor in the development of HPV-associated nonmelanoma skin cancers in immunocompetent hosts. Int J Mol Med 5:405-409

Dumont P, Leu J, Della Pietra AC 3rd, George D, Murphy M (2003) The codon 72 polymorphic variants of p53 have markedly different apoptotic potential. Nat Genet 33(3):357-365

Francisco G, Menezes PR, Neto JE, Chammas R (2010) Arg72Pro TP53 polymorphism and cancer susceptibility: a comprehensive meta-analysis of 302 case-control studies. Int J Cancer 129:920-930

Garcia-Closas M, Kristensen V, Langerod A, Qi Y, Yeager M, Burdett L, Welch R, Lissowska J, Peplonska B, Brinton L, Gerhard DS, Gram IT, Perou CM, Børresen-Dale AL, Chanock S (2007) Common genetic variation in TP53 and its flanking genes, WDR79 and ATP1B2, and susceptibility to breast cancer. Int J Cancer 121:2532-2538

Gaudet MM, Gammon MD, Bensen JT, Sagiv SK, Shantakumar S, Teitelbaum SL, Eng SM, Neugut Al, Santella RM (2008) Genetic variation of TP53, polycyclic aromatic hydrocarbon-related exposures, and breast cancer risk among women on Long Island, New York. Breast Cancer Res Treat 108:93-99

Gochhait S, Bukhari SI, Bairwa N, Vadhera S, Darvishi K, Raish M, Gupta P, Husain SA, Bamezai RN (2007) Implication of BRCA2- 26GA 50 untranslated region polymorphism in susceptibility to sporadic breast cancer and its modulation by p53 codon 72 Arg- Pro polymorphism. Breast Cancer Res 9:R71

Henriquez-Hernandez LA, Murias-Rosales A, Hernandez GA, Cabrera DLA, Draz-Chico BN, Rosales AM (2009) Gene polymorphisms in TYMS, MTHFR, p53 and MDR1 as risk factors for breast cancer: a case-control study. Oncol Rep 22:1425-1433

Higgins JPT, White IR, Wood AM (2008) Imputation methods for missing outcome data in meta-analysis of clinical trials. Clin Trials 5:225-239

Huang XE, Hamajima N, Katsuda N, Matsuo K, Hirose K, Mizutani M, Iwata H, Miura S, Xiang J, Tokudome S, Tajima K (2003) Association of p53 codon Arg72Pro and p73 G4C14-to-A4T14 at exon 2 genetic polymorphisms with the risk of Japanese breast cancer. Breast Cancer 10:307-311

Johnson N, Fletcher O, Palles C, Rudd M, Webb E, Sellick G, dos Santos SI, McCormack V, Gibson L, Fraser A, Leonard A, Gilham C, Tavtigian SV, Ashworth A, Houlston R, Peto J (2007) Counting potentially functional variants in BRCA1, BRCA2 and ATM predicts breast cancer susceptibility. Hum Mol Genet 16:1051-1057
Kalemi TG, Lambropoulos AF, Gueorguiev M, Chrisafi S, Papazisis KT, Kotsis A (2005) The association of p53 mutations and p53 codon 72, Her 2 codon 655 and MTHFR C677T polymorphisms with breast cancer in Northern Greece. Cancer Lett 222:57-65

Kara N, Karakus N, Ulusoy AN, Ozaslan C, Gungor B, Bagci H (2010) P53 codon 72 and HER2 codon 655 polymorphisms in Turkish breast cancer patients. DNA Cell Biol 29(7):387-389

Katiyar S, Thelma BK, Murthy NS, Hedau S, Jain N, Gopalkrishna V, Husain SA, Das BC (2003) Polymorphism of the p53codon 72 Arg/Pro and the risk of HPV type 16/18-associatedcervical and oral cancer in India. Mol Cell Biochem 252:117-124

Kazemi M, Salehi Z, Chakosari RJ (2009) TP53 Codon 72 polymorphism and breast cancer in Northern Iran. Oncol Res 18(1):25-30

Khadang B, Fattahi MJ, Talei A, Dehaghani AS, Ghaderi A (2007) Polymorphism of TP53 codon 72 showed no association with breast cancer in Iranian women. Cancer Genet Cytogenet 173:38-42

Li T, Lu ZM, Guo M, Wu QJ, Chen KN, Xing HP, Mei Q, Ke Y (2002) p53 codon 72 polymorphism (C/G) and the risk of human papillomavirus-associated carcinomas in China. Cancer 95(12):2571-2576

Li J, Y-f G, Pei Y, Deng H-W (2012) The impact of imputation on meta-analysis of genome-wide association studies. PLoS One 7(4):e34486

Lima JM, Serafim PVP, Silva IDCG, Forones NM (2006) Estudo do polimorfismo genético no gene p53 (códon 72) em câncer colorretal. Arq Gastroenterol 43(1):8-13

Lum SS, Chua HW, Li H, Li WF, Rao N, Wei J, Shao Z, Sabapathy K (2008) MDM2 SNP309 G allele increases risk but the T allele is associated with earlier onset age of sporadic breast cancers in the Chinese population. Carcinogenesis 29:754-761

Ma H, Hu Z, Zhai X, Wang S, Wang X, Qin J, Chen W, Jin G, Liu J, Gao J, Wang X, Wei $Q$, Shen $H$ (2006) Joint effects of single nucleotide polymorphisms in P53BP1 and p53 on breast cancer risk in a Chinese population. Carcinogenesis 27:766-771

Ma Y, Yang J, Liu Z, Zhang P, Yang Z, Wang Y, Qin H (2011) No significant association between the TP53 codon 72 polymorphism and breast cancer risk: a meta-analysis of 21 studies involving 24,063 subjects. Breast Cancer Res Treat 125:201-205

Mabrouk I, Baccouche S, El-Abed R, Mokdad-Gargouri R, Mosbah A, Saïd S, Daoud J, Frikha M, Jlidi R, Gargouri A (2003) No evidence of correlation between p53 codon 72 polymorphism and risk of bladder or breast carcinoma in Tunisian patients. Ann N Y AcadSci 1010:764-770

Manning AK, Valley ML, Liu C-T, Rice K, An P, Liu Y, Miljkovic I, Rasmussen-Torvik L, Harris TB, Province MA, Borecki IB, Florez JC, Meigs JB, Cupples LA, Dupuis J (2011) Meta-analysis of Gene-Environment interaction: joint estimation of SNP and SNP $\times$ Environment regression coefficients. Genet Epidemiol 35:11-18

Martin A-M, Kanetsky PA, Amirimani B, Colligon TA, Athanasiadis G, Shih HA, Gerrero MR, Calzone K, Rebbeck TR, Weber BL (2003) Germline TP53 mutations in breast cancer families with multiple primary cancers: is TP53 a modifier of BRCA1? Med Genet 40:e34

Menzel HJ, Sarmanova J, Soucek P, Berberich R, Grünewald K, Haun M, Kraft HG (2004) Association of NQO1 polymorphism with spontaneous breast cancer in two independent populations. Br J Cancer 90:1989-1994

Noma C, Miyoshi Y, Taguchi T, Tamaki Y, Noguchi S (2004) Association of p53 genetic polymorphism (Arg72Pro) with estrogen receptor positive breast cancer risk in Japanese women. Cancer Lett 210:197-203

Ohayon T, Gershoni-Baruch R, Papa MZ, Distelman Menachem T, Eisenberg Barzilai S, Friedman E (2005) The R72P P53 mutation is associated with familial breast cancer in Jewish women. Br J Cancer 92:1144-1148

Olivier M, Eeles R, Hollstein M, Khan MA, Harris CC, Hainaut P (2002) The IARC tp53 database: New online mutation analysis and recommendations to users. Hum Mutat 19(6):607-614

Oluwagbemiga LA, Oluwole A, Kayode AAR (2012) Seventeen years after BRCA1: what is the BRCA mutation status of the breast cancer patients in Africa? - a systematic review. Springer Plus 1:83

Osorio A, Pollán M, Pita G, Schmutzler RK, Versmold B, Engel C, Meindl A, Arnold N, Preisler-Adams S, Niederacher D, Hofmann W, Gadzicki D, Jakubowska A, Hamann U, Lubinski J, Toloczko-Grabarek A, Cybulski C, Debniak T, Llort G, Yannoukakos D, Díez O, Peissel B, Peterlongo P, Radice P, Heikkinen T, Nevanlinna H, Mai PL, Loud JT, McGuffog L, Antoniou AC et al (2008) An evaluation of the polymorphisms Ins16bp and Arg72Pro in p53 as breast cancer risk modifiers in BRCA1 and BRCA2 mutation carriers. Br J Cancer 99:974-977

Petitjean A, Mi A, Al B-D, Hainaut P, Olivier M (2007) TP53 mutations in human cancers: functional selection and impact on cancer prognosis and outcomes. Oncogene 26(15):2157-2165 
Pinto Y, Ibáñez M, Rangel N, Ramírez S, Sánchez W, Vanegas D (2007) Polimorfismos del gen P53 em câncer mamário familiar en una población colombiana. Rev Colomb Cir 22:17-26

Rajkumar T, Samson M, Rama R, Sridevi V, Mahji U, Swaminathan R, Nancy NK (2008) TGFbeta1 (Leu10Pro), p53 (Arg72Pro) can predict for increased risk for breast cancer in south Indian women and TGFb1 Pro (Leu10Pro) allele predicts response to neo-adjuvant chemo-radiotherapy. Breast Cancer Res Treat 112:81-87

Schmidt MK, Reincke S, Broeks A, Braaf LM, Hogervorst FB, Tollenaar RA, Johnson N, Fletcher O, Peto J, Tommiska J, Blomqvist C, Nevanlinna HA, Healey CS, Dunning AM, Pharoah PD, Easton DF, Dörk T, Van't Veer LJ (2007) Breast cancer association consortium: Do MDM2 SNP309 and TP53 R72P interact in breast cancer susceptibility? A large pooled series from the breast cancer association consortium. Cancer Res 67:9584-9590

Schmidt MK, Tommiska J, Broeks A, Leeuwen FEV, Veer LJV, Pharoah PD, Easton DF, Shah M, Humphreys M, Dörk T, Reincke SA, Fagerholm R, Blomqvist C, Nevanlinna H (2009) Combined effects of single nucleotide polymorphisms TP53 TP53ARGP and MDM2 SNP309, and p53 expression on survival of breast cancer patients. Breast Cancer Res 11(6):R89

Siddique MM, Balram C, Fiszer-Maliszewska L, Aggarwal A, Tan A, Tan P, Soo KC, Sabapathy K (2005) Evidence for selective expression of the p53 codon 72 polymorphs: implications in cancer development. Cancer Epidemiol Biomarkers Prev 14:2245-2252

Singh V, Rastogi N, Mathur N, Singh K, Singh MP (2008) Association of polymorphism in MDM-2 and p53 genes with breast cancer risk in Indian women. Ann Epidemiol 18:48-57

Sinilnikova OM, Antoniou AC, Simard J, Healey S, Léoné M, Sinnett $D$, Spurdle AB, Beesley J, Chen X, KConFab, Greene MH, Loud JT, Lejbkowicz F, Rennert G, Dishon S, Andrulis IL OCGN, Domchek SM, Nathanson KL, Manoukian S, Radice P, Konstantopoulou I, Blanco I, Laborde AL, Durán M, Osorio A, Benitez J, Hamann U, Hogervorst FB, van Os TA, Gille HJ HEBON et al (2009) The TP53 Arg72Pro and MDM2 309G4T polymorphisms are not associated with breast cancer risk in BRCA1 and BRCA2 mutation carriers. Br J Cancer 101:1456-1460

Sprague BL, Trentham-Dietz A, Garcia-Closas M, Newcomb PA, Titus-Ernstoff L, Hampton JM, Chanock SJ, Haines JL, Egan KM (2007) Genetic variation in TP53 and risk of breast cancer in apopulation-based case control study. Carcinogenesis 28:1680-1686

Suresh K, Venkatesan R, Chandirasekar R, Kumar BL, Sasikala K (2011) Association of Trp53 arg72pro polymorphic variants with breast cancer - a case control study in south Indian population. Biol Med 3(1):15-22

Suspitsin EN, Buslov KG, Grigoriev MY, Ishutkina JG, Ulibina JM, Gorodinskaya VM, Pozharisski KM, Berstein LM, Hanson KP, Togo AV, Imyanitov EN (2003) Evidence against involvement of P53 polymorphism in breast cancer predisposition. Int J Cancer 103:431-433

Thomas M, Kalira A, Labrecque S, Pim D, Banks L, Matlashewski G (1999) Two polymorphic variants of wild-type $p 53$ differ biochemically and biologically. Mol Cell Biol 19(2):1092-1100

Tommiska J, Eerola H, Heinonen M, Salonen L, Kaare M, Tallila J, Ristimäki A, von Smitten K, Aittomäki K, Heikkilä P, Blomqvist C, Nevanlinna H (2005) Breast cancer patients with p53 Pro72 homozygous genotype have a poorer survival. Clin Cancer Res 11:5098-5103

Trifa F, Karray-Chouayekh S, Mabrouk I, Baccouche S, Khabir A, Sellami-Boudawara T, Gargouri A, Mokdad-Gargouri R (2010) Haplotype analysis of p53 polymorphisms: Arg72Pro, Ins16bp and G13964C in Tunisianpatients with familial or sporadic breast cancer. Cancer Epidemiol 34(2):184-188

Wang-Gohrke S, Becher H, Kreienberg R, Runnebaum IB, Chang-Claude J (2002) Intron 316 bp duplication polymorphism of p53 is associated with an increased risk for breast cancer by the age of 50 years. Pharmacogenetics 12:269-272

Weston A, Godbold JH (1997) Polymorphisms of H-ras-1 and p53 in breast cancer and lung cancer: a meta-analysis. Environ Health Perspect 105:919-926

Zhuo W, Zhang Y, Xiang Z, Cai L, Chen Z (2009) Polymorphisms of TP53 codon 72 with breast carcinoma risk: evidence from 12226 cases and 10782 controls. J Exp Clin Cancer Res 28:115

doi:10.1186/2193-1801-3-749

Cite this article as: Gonçalves et al:: Association of the TP53 codon 72 polymorphism and breast cancer risk: a meta-analysis. SpringerPlus 2014 3:749.

\section{Submit your manuscript to a SpringerOpen ${ }^{\circ}$ journal and benefit from:}

- Convenient online submission

- Rigorous peer review

- Immediate publication on acceptance

- Open access: articles freely available online

- High visibility within the field

- Retaining the copyright to your article

Submit your next manuscript at $\gg$ springeropen.com 